食道癌手術時のリンパ節に悪性リンパ腫をみとめた 1 例 千里保健医療センター新千里病院外科, NTT 西日本大阪病院病理検査科*

$\begin{array}{llllllll}\text { 前 } & \text { 浦義 市 } & \text { 斎 } & \text { 藤 } & \text { 文 } & \text { 田進 久 } \\ \text { 松 } & \text { 永征 一 } & \text { 岡 } & \text { 本 } & \text { 茂* } & & \end{array}$

食道癌切除時の郭清されたリンパ節に悪性リンパ腫をみとめた稀な症例を経験したの で報告する. 症例は67歳男性. 噯下困難を主訴として上部消化管造影にて食道癌を疑わ れ精査, 加療目的にて入院となる. 造影所見では $\mathrm{Mt}$ に長径 $4.0 \mathrm{~cm}$ の陰影欠損をみとめ, 内視鏡では表在隆起型の所見を示し,生検で中分化扁平上皮癌と診断された.CTでは領 域リンパ節の腫大，他臟器浸潤はなく，また遠隔転移もないため一期的手術が可能と診 断し, 胸部食道垔全摘, 胃管利用胸骨後再建（頸部吻合, D2）を行った. 術後の病理診 断では中分化扁平上皮癌, pT1b pN0 M0, stage I, aw(-)ow (-), lyl, v0 だったが 105番リンパ節に悪性リンパ腫（NHL, diffuse mixed type）を併存していた. 免疫組織 学的検討では MT-1 陽性であり, T cell type と診断された。術後経過は良好であり 5 年10カ月の現在いずれの腫瘍の再発もみとめていない.

索引用語：食道癌, 悪性リンパ腫, 重複癌

はじめに

近年になって重複癌の報告では食道癌とリンパ腫の 重複例も報告されているが, 同時性に食道癌とその所 属リンパ節に悪性リンパ腫をみとめた報告はない。今 回われわれは食道癌根治手術時に郭清されたリンパ節 に悪性リンパ腫を併存した症例を経験したので報告す る.

患者：67歳, 男性.

主訴：䠐下困難。

家族歴：特記すべきことなし.

既往歴：50歳，十二指腸潰瘍，保存的治療.

現病歴：1993年11月頃より固形物摂取時に軽い與下 困難感あるも，放置.徐々に症状が強くなったため1994 年 4 月近医で上部消化管造影を受け, 食道に隆起性病 変を指摘され精查, 加療目的にて 5 月 9 日当院外科に 入院となった.

入院時現症：身長 $169 \mathrm{~cm}$, 体重 $67 \mathrm{~kg}$, 負血, 黄㾝を みとめず, 心, 肺異常なし. 腹部は平坦, 柔かで, 肝,

2000 年 3 月 31 日受付 2000 年 6 月 8 日採用 〈所属施設住所〉

于565-0862 吹田市津雲台 1-1-D 6
脾触知せず．表在リンパ節触知せず．

入院時検査所見: RBC 353万 $/ \mu \mathrm{l}, \mathrm{Hb} 12.7 \mathrm{~g} / \mathrm{dl}$, CEA $2.8 \mathrm{ng} / \mathrm{ml}, \mathrm{SCC} 1.5 \mathrm{ng} / \mathrm{ml}$, 生化学的検查：異常 なし，尿所見：正常, 胸部 X線写真：異常なし.

上部消化管造影：食道 $\mathrm{Mt}$ に長径 $4.0 \mathrm{~cm}$ の隆起性病 変をみとめる(図 1 ).

内視鏡所見：門歯より $30 \mathrm{~cm}$ より $4 \mathrm{~cm}$ にわたり広 基性の隆起性病変をみとめるも，ルゴールによる色素 法では他に病変の併存はみられない(図 2 )。生検では 中分化扁平上皮癌であった。

胸部 CT 像：頸部一縦隔内リンパ節の明らかな腫大 はなく, 他藏器への浸潤はなし（図 3 ).

腹部 CT, 超音波検査 : 肝転移,リンパ節腫大はな ᄂ.

入院後経過：上記所見より切除可能な食道癌と診断 され1994年 5 月24日手術施行 (胸部食道亜全摘).

手術所見：右第 5 助間で開胸. 胸水, 癒着はみとめ ず食道の腫瘍は獎膜に露出せず $\mathrm{A} 0$ であり，特に固い リンパ節は触知されなかったが，105番リンパ節が 2 $\mathrm{cm}$ 大に腫大していた．2 群迄のリンパ節郭清を伴う 胸部食道亚全摘, 胃管による胸骨後再建術を行った. なお腹部, 頸部のリンパ節には腫大をみとめなかった。

切除標本の肉眼所見：腫晹は $4.2 \times 2.9 \mathrm{~cm}$ で $0-\mathrm{I}$, 


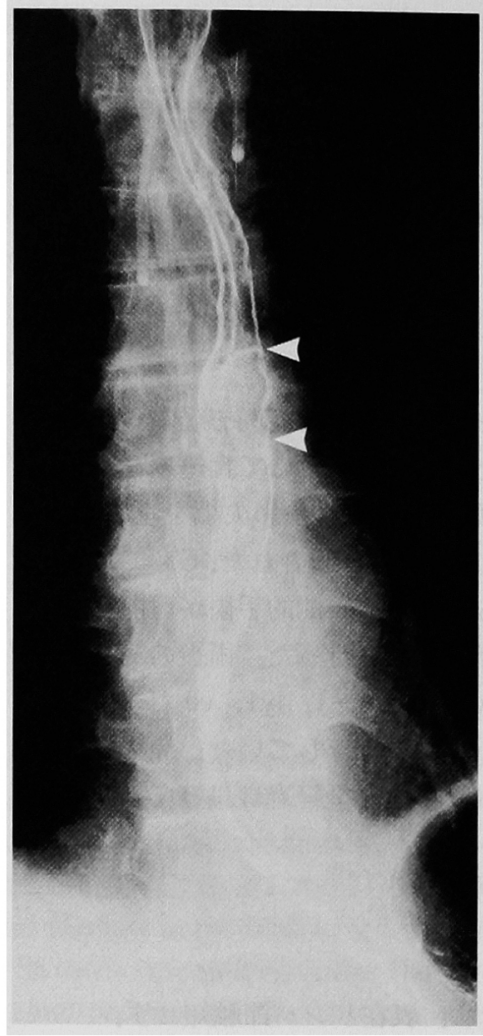

図 1 上部消化管造影：胸部中部食道 (Mt) に不整な隆起性病変をみとめ る。

$\mathrm{pl}$ ，丘状型であり(図 4)，周辺にルゴール不染域をわ ずかに伴う.

病理組織学的所見：食道：中等度分化扁平上皮癌て あり (図 5 ) sm, n0, ly1, v0, ow $(-), a w(-)$. 但 し, 105番リンパ節のうちの 2 個が腫大し,リンパ濾胞 は拡大し，大小不同，不整で構造破壊がみられ，その うち 1 つ（径 $2 \mathrm{~cm}$ 大）には Tcell 形質をもった多形性 の細胞の monoclonal な增殖巣がみとめられた。細胞 は大型と中型で多核を有するものもみられた（図 6 a).また各種の免疫染色ではケラチン(一), EMA $(-), \mathrm{L} 26(-), \mathrm{MB}-1(-), \mathrm{UCHL}-1(+), \mathrm{MT}-1(+)$ であった (図 6 b). 以上より悪性リンパ腫, T cell type (NHL, diffuse, mixed type) と診断された。なお他 の105番リンパ節にはリンパ腫も転移もみられず,他の 切除された所属リンパ節も同様であった。これらの所 見より食道癌 (pStage I, pT1bN0M0) と悪性リンパ 腫 (Ann Arbor 臨床病期分類 stage I A) の併存症例 と診断された。

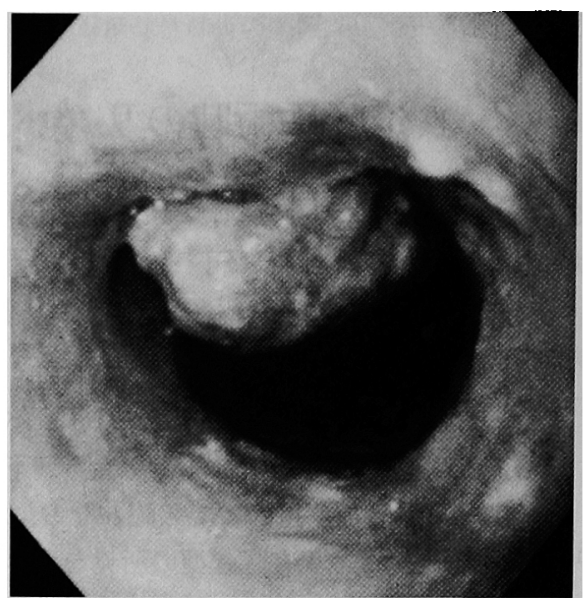

図 2 食道内視鏡検査所見：Mtに $4 \mathrm{~cm}$ 大の 表面不整な $1 / 3$ 周性の隆起性病変をみとめ る.

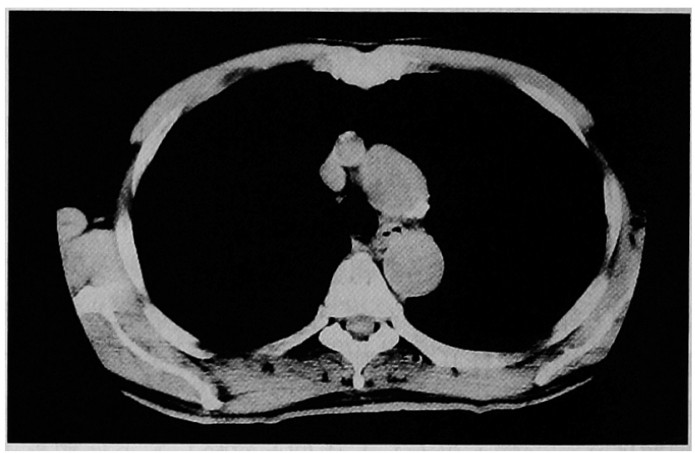

図 3 胸部単純 CT 像：胸部上部食道傍リンパ節等の腫 大は明らかでない。

術後経過：術後経過は順調であり，10日目より経口 摄取開始, 5 週目より tegafur-urasil $600 \mathrm{mg} /$ day p. o. 連続投与と Cisplatin $25 \mathrm{mg} /$ body 5 日連続 i. v. 投与 を行ったが, 終了後 2 週後に白血球減少(最低值1000) までをきたし，G-CSF 投与などで回復した。リンパ腫 については先の食道癌に対する化学療法で著明な骨髄 抑制をきたしたこと，他にリンパ腫を認める所見のな いことなどから入院時にはこちらの疾患に対する化学 療法は行わず外来で経過観察することで退院となっ た。その後は外来でも両者に対する化学療法は行って いない. 術後 5 年 10 月小ずれの疾患の再発もなく健 存である。

考察

重複癌の発生頻度については Warren ら”は3.7\%, 


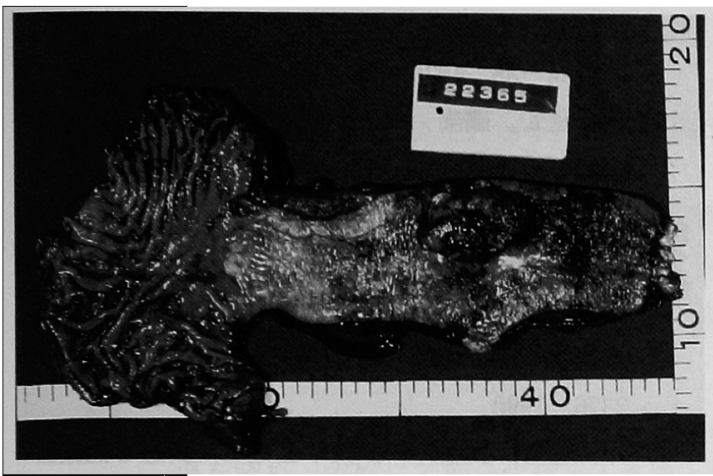

図 4 切除標本肉眼所見 : 中部食道に $4.2 \times 2.9 \mathrm{~cm}$ の表 在隆起型の腫瘍を認める。

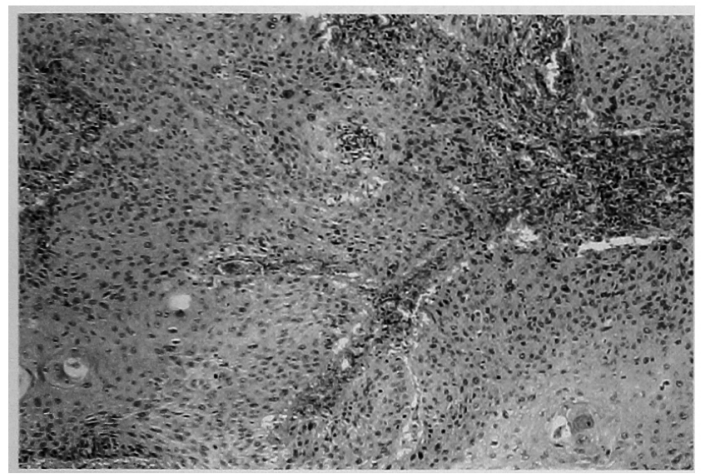

图 5 病理組織学的所見 $(\mathrm{HE}$ 染色 $\times 200)$ ：中等度分化 扁平上皮癌であり深達度は smであった。

赤崎ら ${ }^{2)} 1.56 \%$ と報告している. 食道癌については， 阿保ら (2.1\%), 異時性には136例（1.5\%）の他臟器癌の重 複症例のあることを報告しており，部位別では胃癌が 最も多いとしているが, 他の報告4)放は頭頸部癌がか なり多いとされている，最近の報告では，食道癌と他 の癌の重複例はもう少し頻度が高い様で，10\%前後と

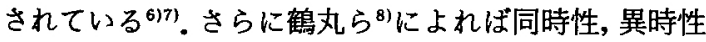
あわせて食道癌の $16.9 \%$ になると報告されている。し かしこのうちでも悪性リンパ尰は 2 例 $(0.9 \%)$ と稀で ある. 落合ら ${ }^{5}$ は他臟器重複癌の発生は $24.6 \%$ になる として，そのうち半数以上が頭頸部癌であるとしてい る.さらに渡辺ら ${ }^{9}$ の報告によると1987年から1992年 では食道重複癌の頻度は $27.0 \% に$ 増加しており, 頭頸 部癌との重複例が急増している。これは頭頸部癌, 食 道癌の治療成績向上が関与しているものと考えてい る. また一方, 悪性血液疾患からみた他蔵器癌の併存

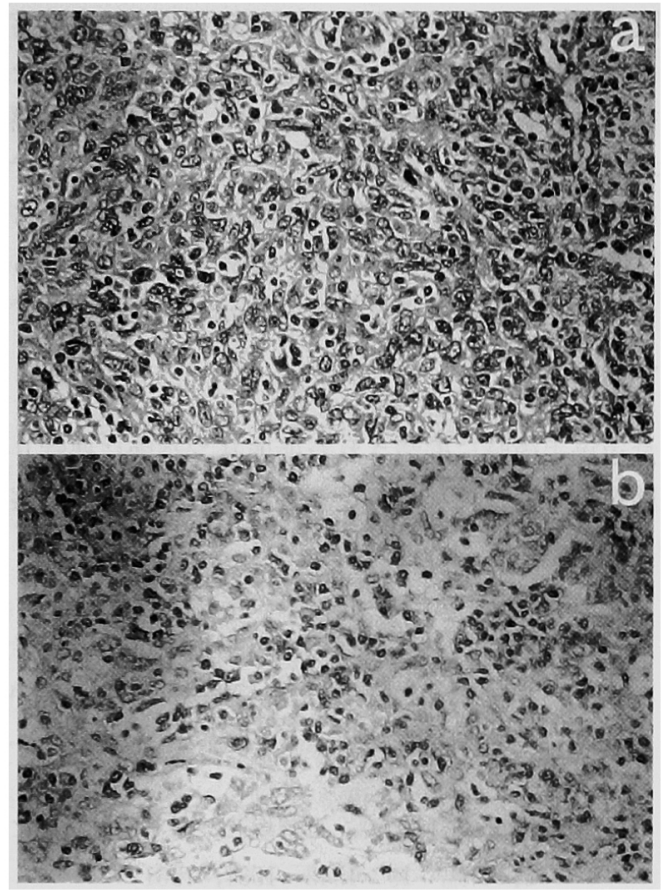

図 6 a 105番リンパ節, 病理組織学的所見 (HE 染 色 $\times 400)$ ：異型性の強い pleomorphic な紐胞の増 殖がみられ，悪性リンパ腫 (NHL, diffuse mixed type) と診断した.

b 同リンパ節の免疫組織学的所見 (MT-1 染 色×400：細胞質に陽性であり Tcell typeであっ た.

頻度は新津ら ${ }^{10)}$ によれば8.3\%とされている.しかし今 回のような消化器癌切除手術時の郭清されたリンパ節 に悪性リンパ腫が併存していた報告は 1 例のみであ

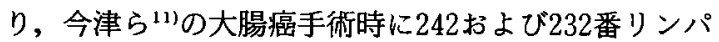
節に B-cell typeの悪性リンパ腫をみとめたという報 告があるのみである．画像診断上あるいは手術時に原 発巣の領域リンパ節の腫大をみとめれば転移，あるい は反応性腫大等を予測するのが妥当であるが，今回の ように転移はみられず悪性りンパ腫をみとめるような 場合は極めて稀と思われる.なおこの症例では術前に 化学療法, 被爆などの既往はない. 術後の化学療法に ついては食道癌が stage I であったこと, 悪性リンパ 腫も 1 個のリンパ節に限局していたことからどのよう な方針にするか判断に苦しんだが，n0ではあるがly1 であることを考慮して食道癌に対する化学療法を優先 させた．結果的には1クールしか施行できず副作用に より中止せざるを得なかった. その後も強い化学療法 
を医療側も㢣戒し，また本人の希望もあり経過観察の

みとしたが両者の再発，再燃はみられていない。なお 術後の放射線治療は行われなかった，異時性重複癌で あれば個々の診断，治療時に対応が決定されるので問 題はないが，同時性で異なる癌種が共存する場合には 進行度などから生命予後により関係すると思われる癌 種に対する治療が優先されているのが現状のようであ る.

\section{結語}

食道癌手術時に郭清された所属リンパ節に悪性リン パ腫をみとめた稀な症例を経験したので文献的考察を 加えて報告した。

\section{文献}

1) Warren $S$, Gates $O$ : Multiple primary malignant tumors. A survey of the literature and a statistical study. Am J Cancer 16:1358-1414, 1932

2）赤崎兼義, 若狭治毅, 石館卓三：原発性重複癌に ついて. 日臨 19:1543-1551, 1961

3）阿保七三郎, 三浦秀男, 工藤 保他: 食道癌と他 臟器重複癌. 外科 Mook 24：119-126, 1982

4）池田 恢, 宮田俶明, 真崎規江 他：食道, 他缄器
重複癌一頭䅡部癌との重複について，癌の臨 $25: 84-88,1979$

5）落合正宏，磯部 橴，安藤幸史他：食道癌と他㵴 器癌の重複例について一特に耳鼻科領域癌との重 複例についての検討一.日臨外医会誌 $46 ： 492-$ 497, 1985

6）篠田雅幸, 高木 厳, 國島和夫：食道癌と他葴器 重複癌症例の检討. 日臨外医会誌 $51: 2371-$ 2376,1990

7）片柳愳雄, 武藤輝一, 田中乙雄他：食道と他臟器 の重複癌症例の検討. 日消外会誌 $24: 968-976$, 1991

8）鶴丸昌彦, 宇田川晴司, 梶山義明他：食道癌との 重複癌。外科治療 $67: 401-407,1992$

9）渡辺 寛：厚生省がん研報1994年度.602-604， 1995

10）新津 望, 梅田正法：高齢者造血器悪性腫瘍患者 における重複癌の検討. 日老医会誌 $33 ： 269-$ 272,1996

11）今津浩喜, 船曳孝彦, 落合正宏 他：大腸癌切除時 の郭清リンパ節に節性覀性リンパ腫を認めた 1

例。日臨外会誌 $59 ： 1592-1595 ， 1998$

\title{
A CASE OF NODAL MALIGNANT LYMPHOMA IN THE REGIONAL LYMPH NODE AT A RADICAL OPERATION FOR ESOPHAGEAL CANCER
}

\author{
Yoshiichi MAEURA, Mahumi SAITO, Nobuhisa UEDA, \\ Seiichi MATSUNAGA and Shigeru OKAMOTO* \\ Department of Surgery, Senri Health and Medical Center, Shinsenri Hospital \\ *Department of Pathology, NTT Nishinihon Hospital
}

A rare case of malignant lymphoma found out at lymph nodes dissection for esophageal cancer is reported. A 67-year-old man who had been suffering from swallowing disturbance was admitted to the hospital for close exploration and treatment. An upper gastrointestinal barium study revealed a filling defect of $40 \mathrm{~mm}$ in size at Mt of the esophagus. Endoscopic study showed the tumor was surface-elevated type and moderately differentiated squamos cell carcinoma, histologically. CT scan showed no lymph node swelling nor invasion into other organs. No distant metastasis was demonstrated. We thought that operation on one-step approach was possible. The patient underwent a subtotal esophagectomy and lymphadnectomy (D2) together with reconstruction using the stomach through posterior sternum. The histopathological diagnosis was moderately differentiated squamous cell carcinoma with pT1bpN0M0, stage I. However, malignant lymphoma which was classified as NHL, diffuse mixed type was detected at the lymph node, \#105. Immunohistochemical study revealed that it was positive for MT-1 and was diagnosed as $T$ cell type. The patient has been doing well without any recurrence as of 5 years and 10 months after the operation. 